\title{
THE HAgue CONVENTION ON THE CIVIL ASPECTS OF INTERNATIONAL CHILD ABDUCTION 1980: THE NEW ZEALAND COURTS' APPROACH TO THE "GRAVE RISK" EXCEPTION FOR VICTIMS OF DOMESTIC VIOLENCE
}

\author{
Allie Maxwell*
}

\begin{abstract}
The Hague Convention 1980 was welcomed by the international community to resolve the emerging issue of international child abduction. The Convention is premised on the assumption that all child abduction is inherently harmful. Thus, it is generally in the best interests of children to be returned to the country of habitual residence as expediently as possible, restoring the status quo.

Domestic violence victims do not fall within the typical abduction paradigm which the Convention was drafted to remedy. New Zealand courts have adopted a narrow approach to the "grave risk" defence, requiring the abducting party to prove that the country of habitual residence cannot adequately protect the child. This is rarely established due to the influence of the principle of comity. This approach therefore effectively blocks the discretionary inquiry, which only occurs once the defence is established, in which the Convention principles can be weighed against the welfare and best interests of the individual child, a consideration paramount in both domestic and international law. Domestic violence makes it unlikely that return will ever be in the child's welfare and best interests. A change in approach is suggested, under which consideration of the adequacy of the habitual residence's protection laws becomes a relevant consideration in the exercise of discretion. This ensures all considerations are given due regard and the safety of young domestic violence victims is better assured.
\end{abstract}

* Submitted as part of the LLB(Hons) programme at Victoria University of Wellington. I would like to thank my superviser, Alberto Costi, for his invaluable guidence and support. 


\section{INTRODUCTION}

The Hague Convention on the Civil Aspects of International Child Abduction 1980 (the Convention) was aimed at resolving the global issue of international child abduction, exacerbated in recent times by technological advances in air travel, rising inter-racial marriages and a difficulty in adjudicating across geographical borders. ${ }^{1}$

As the Convention was a welcomed development, "it has generally been insulated from the scholarly and critical examination to which any area of the law should be subjected". ${ }^{2}$ It is only in recent years that the Convention has sparked academic debate.

This article explores the current approach by New Zealand courts to the "grave risk" exemption in cases of domestic violence. New Zealand courts, similarly to other jurisdictions, have adopted a narrow approach, requiring the abductor to show that the habitual residence cannot adequately protect the child, in order to establish the defence. Due to the principle of comity, which emphasises respect for another nation's legislative and judicial jurisdiction, it is rare that courts will make such a finding as this may be seen to undermine the principle. Thus, the current approach effectively blocks the latter discretionary inquiry which balances Convention purposes and a child's welfare and best interests in deciding whether a return order should be made. Whilst this aligns with Convention principles of deterrence, speedy return and a focus on forum over merits, victims of domestic violence are different to the "stereotypical abductor" the Convention was drafted to deal with, and consequently a different approach is needed.

This article suggests evidence of domestic violence should suffice to establish the "grave risk" defence, with examination of the other country's legal system being considered in the exercise of discretion. This ensures the welfare and best interests inquiry is given due weight alongside other considerations, guaranteeing better protection for victims. The compulsory appointment of a lawyer for the child in these situations may also help to safeguard the child's welfare and best interests, particularly as undertakings have been largely ineffective.

The legal framework, including the drafting of the Convention, key purposes and its subsequent implementation in New Zealand will firstly be outlined, followed by a discussion of the relationship between the Convention and domestic violence. The core part of this article will consider the current approach by New Zealand courts in domestic violence cases, with comparison to overseas jurisdictions, and the consequent issues with this approach. The final paragraphs suggest an adjustment of approach and briefly examine the possible benefits and critiques of such an adjustment.

1 Convention on the Civil Aspects of International Child Abduction 1343 UNTS 97 (opened for signature 25 October 1980, entered into force 1 December 1983) [Hague Convention].

2 Miranda Kaye "The Hague Convention and the Flight From Domestic Violence: How Women and Children Are Being Returned by Coach and Four" (1999) 13 IJLPF 191 at 192. 


\section{LEGAL FRAMEWORK}

\section{A Introduction to the Convention}

International child abduction, put simply, refers to situations where a child is abducted (often by a parent) from their home country to another state. ${ }^{3}$ Prior to the Convention, the legal position was unsatisfactory. ${ }^{4}$ Children were abducted to countries with a different legal system, social structure and culture, with the physical distance exacerbating issues in locating the child and petitioning for return. ${ }^{5}$ The necessity of a global solution and clear legal framework had become urgent by the 1970s, and the Convention was subsequently drafted. ${ }^{6}$

It was previously unclear which law should govern the dispute, an issue fundamental in private international law. The Convention clarified the primary role of the country of habitual residence in determining issues of custody. ${ }^{7}$ This led to the notion that Hague proceedings were therefore focused on determining the appropriate forum, rather than a merits inquiry of the case, the latter being best suited to the country of habitual residence in accordance with its own social and cultural beliefs.

The Convention streamlines the return process by providing a procedural framework which operates through the Central Authorities of each state. ${ }^{8}$ The Central Authority, part of New Zealand's Ministry of Justice, plays a vital role in securing voluntary return of the child, and if this is unachievable, facilitating judicial proceedings for the petitioning party. ${ }^{9}$ This role may also extend to enforcement, as in Butler v Craig, where it was stated "the Central Authority should take prompt steps to enforce the return order". ${ }^{10}$

3 Rebecca Mockett "The Hague Convention on International Child Abduction: Policy, Issues and Future Reforms" (2007) 1 NZLSJ 199 at 199.

4 David McClean The Hague Convention on International Child Abduction, Explanatory Documentation for Commonwealth Governments (Commonwealth Secretariat, London, 1997) at 2.

5 Hague Conference on Private International Law "Outline: Hague Child Abduction Convention" (May 2014) <www.hcch.net> at $1[\mathrm{HCCH}]$.

6 Lynda Herring "Taking Away the Pawns: International Parental Abduction and the Hague Convention" (1995) 20 NCJ Intl L \& Com Reg 137 at 138.

$7 \quad \mathrm{HCCH}$ "Explanatory Report" (1982) <www.hcch.net> at 429.

8 Hague Convention, above n 1 , art 7.

9 Hague Convention, above n 1; and Jennifer Wademan "The Hague Convention on International Child Abduction: The role of the Central Authority in Court Proceedings" (2008) 6 NZFLJ 105 at 105.

10 Butler v Craig [2008] NZCA 198, (2008) 28 FRNZ 112 at [63]. 
As the Convention is not self-executing, its enforceability depends on signatory countries enacting implementing legislation. ${ }^{11}$ There are currently 95 contracting parties to the Convention, including New Zealand. ${ }^{12}$ On 1 March 2017, Pakistan became the 96th signatory to the Convention.

\section{$B$ Purposes of the Convention}

Article 1 of the Convention outlines the primary objects: securing prompt return of the child, and ensuring the rights of custody and access under the laws of one contracting state are effectively respected in the other. ${ }^{13}$ The latter speaks to the principle of comity, reflecting the idea that any dispute on the question of a child's custody or residence should take place before the authorities in the country of habitual residence. ${ }^{14}$ Comity may be expanded as referring to "considerations of high international politics concerned with maintaining amicable and workable relationships between nations". ${ }^{15}$ Whilst a desire to uphold international comity underpins the application of the Convention in this area, it is important to keep in mind that comity is implemented solely through courtesy and is not legally binding. ${ }^{16}$ The Convention aims to balance the role of a merits inquiry and the need to respect legal relations which may underlie such situations. ${ }^{17}$

The summary return mechanism is another central purpose of the Convention, referring to the prompt return of the child, aimed at mitigating the effects of the abduction on the child and providing a deterrent to any individuals contemplating abduction. ${ }^{18}$ The general idea is that parents will be less likely to abduct if the child will be returned immediately.

Some have argued that the Convention does acknowledge a child's welfare and best interests; however, this is focused on children's interests generally. ${ }^{19}$ Abduction of a child is presumed to be contrary to their welfare as it removes them from a known carer and environment. ${ }^{20}$ By presuming all

11 Rebecca Rose "Interpretations of the Hague Child Abduction Convention 1980 in New Zealand Since COCA: Cause for Concern?" (2008) 16 Wai L Rev 111 at 116.

$12 \mathrm{HCCH}$ "Convention of 25 October 1980 on the Civil Aspects of International Child Abduction: Status Table" (20 May 2016) <www.hcch.net>.

13 Hague Convention, above n 1, art 1.

14 Kaye, above n 2, at 192.

15 Joel R Paul "Comity in International Law" (1991) 32 Harv Intl LJ at 4.

16 Malcolm Shaw International Law (7th ed, Cambridge University Press, Cambridge, 2014) at 2.

$17 \mathrm{HCCH}$, above $\mathrm{n} 7$, at 428 .

18 Anne-Marie Hutchinson, Rachel Roberts and Henry Setright International Parental Child Abduction (Jordan Publishing, London, 1998) at 4.

19 Mockett, above n 3, at 207; and Jessica Davies "Untapped Potential: Rethinking the Human Rights Defence in International Child Abduction" (2013) 7 NZFLJ 235 at 236.

20 Pauline Tapp "Welfare of the Child and Abduction" [2007] NZLJ 77 at 80. 
child abductions are inherently harmful and that summary return is in the best interests of the child, the interests of each individual child are in a certain sense sacrificed for the deemed welfare of the group. ${ }^{21}$ This article suggests that domestic violence cases are different. A child who is abducted from a situation of domestic violence will likely have different interest and welfare concerns to the paradigm group.

The aforementioned purposes are strongly reflected in the interpretation and enforcement of the Convention.

\section{Implementation in New Zealand and Framework of a Claim}

The Convention had strong bipartisan support from the New Zealand government, with statements in Parliament accentuating the cruelty of child abduction and strong need to amend the inadequate current law. ${ }^{22}$ The New Zealand Law Society also supported the adoption of the Convention, expressing the hope that it would bring considerable improvement to an unsatisfactory area of law. ${ }^{23}$ The Convention was initially incorporated in the Guardianship Amendment Act 1991 until the Care of Children Act 2004 (COCA) became the implementing statute. ${ }^{24}$

In the Convention text, the defences are found in different articles. When implemented in New Zealand statute, the decision was made to codify the defences in a single section to increase clarity and accessibility. Thus what was art 13(b) in the Convention is now found in s 106(1)(c) alongside the other defences. The change in format was the major change which occurred in incorporation, with the language remaining unchanged.

While it is relatively easy to establish an application for return of a child under s 105, courts have taken a narrow approach to s 106 defences, ensuring prompt return remains the recurrent outcome. ${ }^{25}$ Applications for the return of an abducted child can be made if the court is satisfied that the child is present in New Zealand, was wrongfully removed in breach of custody rights being exercised at the time of removal, and was habitually resident in the other contracting state. ${ }^{26}$ Under s 105(2), courts must order prompt return unless one of the grounds in s 106(1) is established to the satisfaction of the court. The permissive language in s 106(1) makes it clear that the court has a residual discretion in

21 Zoran Ponjavic and Veljko Vlaskovic "Space for the Child's Best Interests inside the Hague Convention on the Civil Aspects of International Child Abduction" (2014) 16 Rev Eur L 45 at 51.

22 (10 April 1991) 513 NZPD 1200-1201.

23 David Brown New Zealand Law Society Seminar on the Abduction of Children to Overseas Countries (April 1988).

24 Care of Children Act 2004, pt 2, subpt 4.

25 Rose, above n 11, at 122.

26 Section 105(1). 
regards to making a return order following the establishment of any of the defences. ${ }^{27}$ Thus, the establishment of a defence does not automatically mean that a return order will not be made.

The defence at focus in this article, often referred to as the "grave risk" defence, is found in $\mathrm{s}$ 106(1)(c):

(c) $\quad .$. there is a grave risk that the child's return -

(i) would expose the child to physical or psychological harm; or

(ii) would otherwise place the child in an intolerable situation[.]

The "grave risk" exception is the Convention's most litigated and successfully evoked exception. ${ }^{28}$ It is the defence most often relied on in domestic violence cases, hence its central role in this article.

\section{Application and Return Rates}

Since the Convention was signed, there has been a marked increase in return applications, with 2,321 applications made in 2008, contrasted with only 1,151 applications in $1999 .{ }^{29}$ Given that one of the central aims of the Convention is deterrence, this finding is somewhat disconcerting. New Zealand has a judicial return rate of approximately 78 per cent. ${ }^{30}$ Overall, New Zealand's return rate is increasing which is notable as the global return rate has been steadily declining. ${ }^{31}$ Some have praised New Zealand's "long-standing exceptional record of orders for return" but this article suggests perhaps success ought instead to be measured by the safety and well-being of abducted children, which is not dependent on return orders. ${ }^{32}$

\section{DOMESTIC VIOLENCE AND THE CONVENTION}

The plight of domestic violence victims has been recognised as an increasingly important issue in recent decades. ${ }^{33}$ The need to balance expeditious proceedings and the protection of vulnerable

27 Secretary for Justice v HJ [2006] NZSC 97, [2007] 2 NZLR 289 at [139]; and Pauline Tapp "Child Abduction" [2008] NZLJ 163 at 163.

28 Rose, above n 11, at 124 .

29 Nigel V Lowe and Victoria Stephens "Global Trends in the Operation of the 1980 Hague Abduction Convention" (2012) 46 Fam LQ 41 at 45.

30 At 55.

31 At 56.

32 Rose, above n 11, at 132.

33 Mockett, above n 3, at 230. 
children was recognised as a pressing issue in the most recent Special Commission on the Convention. ${ }^{34}$

The drafters of the Convention did not turn their minds to the possibility that the abducting party may be fleeing domestic violence and resultantly the Convention text omits any reference to domestic violence. ${ }^{35}$ This may be due to domestic violence not being a widely recognised issue during the 1970s when the Convention was drafted, especially within the context of child abduction. As there is no definition of domestic violence in the text, for the purposes of this article, the definition in the Domestic Violence Act 1995, meaning any physical, sexual or psychological abuse which occurs within a domestic relationship, is useful as it reflects the various forms of abuse which may present. ${ }^{36}$ Whilst some academics within this area have focused on the threshold required by the "grave risk" defence, this article accepts that domestic violence will generally satisfy the "grave risk" threshold, classifiable either as an intolerable situation or physical or psychological harm under s 106(1)(c). Thus, the primary barrier for domestic violence victims in successfully resisting a return order is proving the inadequacies of the habitual country's legal system.

The Convention was drafted in accordance with the idea of a stereotypical abductor. The paradigm case was of a father who, becoming frustrated due to a lack of access after courts granted sole custody to the mother, abducts the child. ${ }^{37}$ However, there has been a subsequent gendered shift from abducting non-custodial fathers to abducting primary-carer mothers, producing a "significant change in the motivations for, and dynamics underpinning, international parental child abduction since the Convention was drafted". ${ }^{38}$ One of these motivations is escape from domestic violence. Statistics indicate mothers now comprise approximately 69 per cent of abducting parents, with 72 per cent being the primary caregivers. ${ }^{39}$ This shift in the typical offender profile means that the purposes the Convention was drafted to achieve are perhaps less relevant. Arguably if a child is not being removed from a primary caregiver, as originally premised, prompt return may not be in the best interests of the

$34 \mathrm{HCCH}$ "Conclusions and Recommendations and Report of Part I of the Sixth Meeting of the Special Commission on the practical operation of the 1980 Hague Child Abduction Convention and the 1996 Hague Child Protection Convention" (1-10 June 2011) <www.hcch.net> at 32.

35 Rhona Schuz The Hague Child Abduction Convention: A Critical Analysis (Hart Publishing, Oxford, 2013) at 58 .

36 Domestic Violence Act 1995, s 3.

37 Peter Boshier "The strengths and weaknesses of the Hague Convention of 25 October 1980 on the Civil Aspects of International Child Abduction - A New Zealand perspective" (2009) 6 NZFLJ 250 at 252.

38 Danielle Bozin-Odhiambo "Constructing 'the best interest of the child' legal standard: Hague Child Abduction Convention return proceedings and beyond" (2014) 8 NZFLJ 26 at 26.

39 Lowe and Stephens, above n 29, at 43-44. 
individual child where the harm resulting from the abduction may be less severe than the preabduction setting if violence is present.

Alongside the rising awareness of the prevalence and significant harm caused by domestic violence, there has been a coinciding rise in the need for greater recognition of children's rights and protections. The Convention, as mentioned, focuses on children's interests generally. In recent times, due to this rising awareness, there has been a more sustained judicial focus on securing the compatibility of the Convention with the individual child's welfare and best interests. ${ }^{40}$ International treaties have codified the importance of children's rights, significantly the Convention on the Rights of the Child 1990 (UNCROC). ${ }^{41}$ COCA was intended to improve New Zealand's compliance with international obligations, particularly UNCROC. ${ }^{42}$ Thus, New Zealand's domestic legislation stresses the fundamental principle that the welfare and best interests of a child should be the paramount consideration. ${ }^{43}$ Clearly, a child's welfare and best interests require protection from all forms of domestic violence.

Global problems have been created by the Convention drafters' omission of domestic violence and other contemporary trends from the abduction paradigm. ${ }^{44}$ Despite the realisation that abductors may be fleeing from domestic violence, almost no attention has been given to what the law's response to these abductions should be. ${ }^{45}$ Quillen comments that, whilst there has been a positive trend emerging in regard to recognising the unique position of domestic violence in proceedings, it remains uncertain whether this progress will continue and subsequently become institutionalised. ${ }^{46}$ Despite domestic violence not being recognised as a pressing issue at the time of drafting, the gendered shift in the abduction profile and increasing recognition of the importance of protecting a child's welfare and best interests ought to be enough to highlight that the current approach is disjointed from modern society. It should not be the case that a domestic violence victim's ability to defeat a return application

40 John Caldwell "Child Abduction Cases: Evaluating Risks to the Child and the Convention" (2008) 23 NZULR 161 at 161.

41 Convention on the Rights of the Child 1577 UNTS 3 (opened for signature 20 November 1989, entered into force 2 September 1990), art 3.

42 (9 November 2004) 621 NZPD 16715.

43 Care of Children Act 2004, s 4(1).

44 Rose, above $\mathrm{n} 11$, at 128.

45 Merle H Weiner "International Child Abduction and the Escape from Domestic Violence" (2000) 69 Fordham L Rev 593 at 632.

46 Brian Quillen "The New Face of International Child Abduction: Domestic Violence Victims and Their Treatment under the Hague Convention on the Civil Aspects of International Child Abduction" (2014) 29 Texas Intl LJ 621 at 622 . 
rests on fortuity and the judge's sympathy, rather than any principled rule of law. ${ }^{47}$ Domestic violence is an issue which continues to permeate many aspects of social life, including child abduction, and cannot be adequately addressed until it is acknowledged as a problem requiring a unique approach, different from the mischief originally targeted by the Convention.

\section{CURRENT APPROACH BY NEW ZEALAND COURTS AND OVERSEAS JURISDICTIONS TO THE "GRAVE RISK" DEFENCE}

\section{A Approach by New Zealand Courts}

Although every situation of international child abduction is factually distinct, the approach by New Zealand courts in situations involving domestic violence is analogous across cases.

Though not explicitly stated in the Convention, it is judicially settled in New Zealand that the requisite grave risk in $\mathrm{s} 106(1)(\mathrm{c})$ must be associated with the risk of return of the child to the home country rather than return to the other parent. ${ }^{48}$ Therefore, in order to establish the "grave risk" exception, the abducting party must establish that the habitual residence is incapable of protecting the child from future harm. ${ }^{49}$ The unanimous decision of the Court of Appeal in $A v A$, one of the leading cases in this area, noted that where a system of law of the country of habitual residence makes the best interests of the child paramount and provides mechanisms by which the best interests of the child can be protected, it is for the courts of that country, and not the country to which the child has been abducted, to determine their best interests. ${ }^{50}$ The High Court recently confirmed that this remains an accurate statement of New Zealand law, adding that the establishment of this defence is not an easy task. ${ }^{51}$ The operation of the principle of comity constrains judges from allowing the defence in situations of domestic violence as it is seen to be saying the judicial system of the habitual residence is unable to protect the child on return. ${ }^{52}$

The narrow approach of New Zealand courts to the "grave risk" defence can be illustrated by a number of recent cases. Venning $\mathrm{J}$ in ASM $v$ DPM stressed that in order to establish the "grave risk" defence, the father needed to show both a risk of harm and that the courts in Bulgaria would not

47 Weiner, above $\mathrm{n} 45$, at 599 .

48 HJ v Secretary for Justice [Habitual residence] [2006] NZFLR 1005 (CA) at [31]; Caldwell, above n 40, at 176; and Margaret Casey and Lex de Jong New Zealand Law Society Seminar on the Hague Convention on the Civil Aspects of Child Abduction (March 1995) at 17.

49 Peter Boshier "Care and protection of children: New Zealand and Australian experience of cross-border cooperation" (2005) 5 NZFLJ 63 at 68

$50 A v A[1996]$ NZFLR 529 (CA) at 536.

51 Mikova v Tova [2016] NZHC 1983 at [39].

52 Mockett, above n 3, at 208. 
protect the proper interests and welfare of $\mathrm{A} .{ }^{53}$ Venning $\mathrm{J}$ went on to suggest that the court must presume, in the absence of evidence to the contrary, that Bulgaria, as a contracting state to the Convention, has a family law system capable of protecting children. ${ }^{54}$ Thus, there appears to be a presumption that contracting states will have adequate legal systems to protect children, further restricting the defence and making the task of establishing it even more insurmountable for the abductor. Dreadman v Loche, drawing on HJ v Secretary for Justice [Habitual Residence] and Av A, outlined key principles which should be considered in these types of cases. ${ }^{55}$ The Convention is concerned with the appropriate forum for determining the best interests of the child, with focus on the situation of the child and not the abductor. ${ }^{56}$ The person seeking to rely on the defence must satisfy the court that return to the country will threaten the child's safety because protection cannot be provided for the child upon return. ${ }^{57}$ Such considerations are deliberated against a framework which strongly endorses return. ${ }^{58}$

It is only after the defence is established that the court will weigh all relevant factors to determine whether to exercise its residual discretion and order return. When the discretionary inquiry arises, courts weigh the Convention purposes (prompt return being in the general best interests of the child, deterrence and comity between contracting states) alongside the circumstances of the case which established the defence, and the wider consideration of a child's rights and welfare. This approach was confirmed by the majority of the Supreme Court in Secretary for Justice v HJ. ${ }^{59}$ Whilst this case focused on the s 106(1)(a) "settled" defence, its approach to the exercise of discretion was adopted with respect to the "grave risk" exception by the Court of Appeal in Smith v Adams, which further emphasised that it would be difficult to envisage a situation in which the "grave risk" defence was established yet Convention policy outweighed the interests of the child. ${ }^{60}$ Whilst these cases indicate the willingness of courts to engage in a welfare and best interests inquiry, the abductor must successfully establish s 106(1)(c), which acts as a precursor to the discretion exercise. If the abductor cannot show the country of habitual residence is incapable of protecting the child upon return, the welfare and best interest of the child will not even be considered.

$53 A S M v D P M$ [2016] NZHC 137, [2016] NZFLR 747 at [20].

54 At [32].

55 Dreadman v Loche [2015] NZFC 3002.

56 At [55].

57 At [55].

$58 S \vee S$ [1999] NZFLR 641 (CA) at [9].

59 Secretary for Justice v HJ, above n 27, at [68]; and Tapp "Child Abduction", above n 27, at 164.

60 Smith v Adam [2007] NZFLR 447 (CA) at [13]-[14]. 
We can see that incompatibility exists between promoting comity between contracting states on the one hand, and on the other, the need to adequately protect a child by assessing the individual child's best interests during proceedings. The narrow focus on adequacy of a habitual residence's child protection laws effectively blocks the discretionary inquiry and this incompatibility is most often resolved in favour of facilitating comity. ${ }^{61}$

\section{B Overseas Approaches}

Whilst generally analogous, other jurisdictions are beginning to recognise the central role child protection and the interests inquiry should play in proceedings. A possible reason for this may be the impact of UNCROC, or perhaps a greater judicial willingness to interpret and apply the law in a manner consistent with prioritising protection.

Australian judges assess the habitual residence's child protection laws, considering whether protective legislation in the requesting state is functioning and implemented in practice, not just in theory. ${ }^{62}$ In some respects, this may be seen to go beyond the New Zealand approach, which in the absence of evidence to the contrary, seems to presume other contracting states will have adequate child protection laws. In DP $v$ Commonwealth Central Authority the majority rejected the development of worldwide judicial authorities, calling for the defence to be narrowly construed. ${ }^{63}$ Bozin has attempted to explain this departure by suggesting that in Australia, whilst the Family Court continues to apply a restrictive interpretation of the "grave risk" defence, the High Court has been seen in some cases to prefer a broader interpretation, better balancing the considerations of comity and the welfare of the individual child. ${ }^{64}$

England has also adopted a comparative approach. In Re E (Children) (Abduction: Custody Appeal), the Supreme Court considered that, where allegations of domestic violence are made, courts firstly inquire whether a grave risk exists and, secondly, how the child will be protected from this risk, considering the protection mechanisms in the habitual residence. ${ }^{65}$ However, it was acknowledged in this decision that tension exists between "the inability of the court to resolve factual disputes between the parties and the risks that the child will face if the allegations are in fact true". ${ }^{66}$ In recent times, the English judiciary has acknowledged that the need for swift return under the Convention must be

61 Bozin-Odhiambo, above n 38, at 27.

$62 \mathrm{HCCH}$, above n 34, at 34 .

63 DP v Commonwealth Central Authority [2001] HCA 39 at [155].

64 Danielle Bozin "The Hague Child Abduction Convention's Grave Risk of Harm Exception: Traversing the Tightrope and Maintaining Balance between Comity and the Best Interests of the Child" (2016) 35 U Tas L Rev 24 at 24.

$65 \operatorname{Re}$ E (Children) (Abduction: Custody Appeal) [2011] UKSC 27, [2012] 1 AC 144 at [36].

66 At [36]. 
subject to considerable qualifications, with increasing recognition that the objective of prompt return must not be allowed to outweigh the best interests of the child. ${ }^{67}$ Baroness Hale remarked in Re D that it is inconceivable that a court which reached the conclusion there was a grave risk would nevertheless return the child to face that fate. ${ }^{68}$ The House of Lords has stressed it was not the policy of the Convention that children should be put at serious risk of harm. ${ }^{69}$ Perhaps England is beginning to recognise the flaws in the current approach and the importance of prioritising protection. Promisingly, the passage by Baroness Hale was recently cited as being accepted by counsel in the 2016 New Zealand case of $K N v C N .^{70}$

The Canadian judiciary has expressed similar dissatisfaction with the narrow approach, though it continues to follow an approach comparable to New Zealand's. Indication of dissatisfaction may be illustrated by the early case of Pollastro $v$ Pollastro in which the Ontario Court of Appeal declined an order to return a six-month-old child to California due to evidence of domestic abuse, despite the child herself not being physically harmed, as the court found the child's interests were "inextricably tied to her [mother's] psychological and physical security". ${ }^{71}$ There seems to be a growing awareness of the different forms of abuse which may harm children and a subsequent recognition of this by some jurisdictions. One of the aforementioned Dreadman v Locke principles states the focus ought to be on the situation of the child and not the abducting parent, but perhaps a wider interpretation of abuse as witnessed in Canada would be more in line with the understanding of domestic violence as presenting in both physical and psychological forms.

The United States has taken a somewhat different approach, giving more explicit domestic recognition to the plight of domestic violence victims, with Congress passing the International Parental Kidnapping Crime Act 1993 (IPKCA). This Act makes it a felony to remove or retain a child under 16 with intent to obstruct the lawful exercise of parental rights. This differs from the Convention as it provides a specific defence for parties fleeing from domestic violence. ${ }^{72}$ However, it has been stressed that whilst IPKCA provides a criminal remedy in international abduction cases, it is not intended to detract from the operation of the Convention. ${ }^{73}$ Courts continue to be explicit in their reluctance to use the defence, and to link domestic violence with a grave risk of harm, despite this

67 Adrian Briggs Private International Law in English Courts (Oxford University Press, Oxford, 2014) at 987.

68 Re D (Abduction: Rights of Custody) [2006] UKHL 51, [2007] 1 AC 619 at [55].

69 Re M (Children) (Abduction: Rights of Custody) [2007] UKHL 55, [2008] 1 AC 1288 at [45].

$70 K N v C N[2016]$ NZHC 2049 at [29].

71 Pollastro v Pollastro (1999) 43 OR (3d) 485 (ONCA) at [34].

72 International Parental Kidnapping Crime Act 18 USC § 1204(c)(2).

73 National Criminal Justice Reference Centre A Report to the Attorney General on International Parental Kidnapping (OJJDP Report, April 1999) at 34. 
running counter to the weight of social science research. ${ }^{74}$ Ultimately, United States court decisions accord with international precedent, realising the need to respect the jurisdictional authority of other signatory countries in order to best uphold the Convention purposes. ${ }^{75}$

In an article contrasting the implementation of the Convention in the United States and Japan, the authors noted the most significant difference between the policies was in their recognition of domestic violence. ${ }^{76}$ Whilst the United States, similarly to other Commonwealth countries, fails to expressly give weight to domestic violence outside of the IPKCA, Japan's Convention implementation law affirms domestic violence as a factor which must be evaluated as a potential risk in proceedings. ${ }^{77} \mathrm{~A}$ possible reason for this approach may be that Japan signed the Convention in 2013, during a decade in which the plight of domestic violence victims has been both recognised and prioritised as an important societal issue, a pivotal difference from when the Convention was initially signed some three decades prior by New Zealand, the United States, Canada and Australia.

Consideration of other jurisdictions may be seen as allowing some scope for New Zealand to reconsider its current interpretation and application of the Convention. As consistency is of central importance when applying international agreements, it is promising to see other Convention states beginning to recognise the importance of prioritising protection, rather than strictly enforcing prompt return in domestic violence situations, where such Convention purposes are of lesser significance.

\section{$V$ ISSUES WITH THE CURRENT NEW ZEALAND APPROACH}

\section{A Example of Application}

The recent High Court case of Red $v$ Red illustrates the current approach by New Zealand courts. The mother abducted the children to New Zealand, and the father filed Hague proceedings, alongside filing for custody on the child's return. ${ }^{78}$ The mother argued that returning the children would expose them to a grave risk, as she and the children, especially the eldest child $\mathrm{W}$, were subject to serious physical and psychological abuse, including assault with a taser and W's arm being broken, culminating in an interim restraining order. ${ }^{79}$ In the Family Court, Judge Turner ordered return as

74 William Vesneski, Taryn Lindhorst and Jeffrey Edleson "US Judicial Implementation of the Hague Convention in Cases Alleging Domestic Violence" (2011) 62 Juv \& Fam Court J 1 at 16.

75 Carrie Nelson "Recent United States' Interpretations of Article 13(b) of the Hague International Child Abduction Convention" (2001) 15 Temp Intl \& Comp LJ 297 at 310.

76 Sawako Yamaguchi and Taryn Lindhorst "Domestic Violence and the Implementation of the Hague Convention on the Civil Aspects of International Child Abduction: Japan and U.S. Policy" (2016) 17 J Int Womens Stud 16 at 24.

77 At 24.

$78 \operatorname{Red} v \operatorname{Red}[2016]$ NZHC 340 at [58].

79 At [12]. 
there was limited evidence to support the mother's allegations, and the Australian legal system considers a child's welfare and best interests to be paramount, offering a variety of welfare and statutory agencies which would protect the mother and children upon return. ${ }^{80}$ Expert evidence obtained by the mother in New Zealand strongly opposed return to Australia, highlighting the risk that this might trigger PTSD symptomatology and self-harm behaviour in W. ${ }^{81}$ Nation J, however, agreed with Judge Turner and ordered return of the children on appeal. ${ }^{82}$

At first blush, the "grave risk" defence appears a useful mechanism for domestic violence victims. However, in practice, the narrow approach by courts allows allegations of serious violence to be marginalised in favour of the inquiry into the adequacy of a habitual residence's protection laws.

\section{B Protection of Victims}

Simply because a country has protection laws in place does not mean domestic violence victims are not at risk of harm if a return order is made. The current approach of New Zealand courts fails to recognise this.

The courts should not limit an inquiry to the protection offered by the country of habitual residence, but ought also consider the lethality of the batterer ${ }^{83}$ If a woman leaves a violent partner, she and the children remain vulnerable to stalking, assault and continued psychological abuse. ${ }^{84}$ Research indicates victims of domestic violence are most vulnerable in the period after leaving an abusive partner, and in 23 per cent of domestic violence homicides, protection or restraining orders were in place. ${ }^{85}$ The Australian Law Commission commented that bringing return proceedings under the Convention may in and of itself be a form of abuse, as abusers misuse the Convention to exercise continued control over partners and children. ${ }^{86}$ Fisher $\mathrm{J}$ in $S v S$ observed that circumstances may arise where the habitual residence is incapable of protecting the child as the requesting parent is so dangerous that even suitably warned state agents are unable to assure sufficient protection. ${ }^{87}$ Whilst the use of undertakings is increasing in domestic violence cases, courts cannot guarantee

80 At [15].

81 At [92].

82 At [106].

83 Weiner, above $\mathrm{n} 45$, at 659

84 Kaye, above n 2, at 193.

85 Janet Johnson, Victoria Lutz and Neil Websdale "Death by Intimacy: Risk Factors for Domestic Violence" (2000) 20 Pace L Rev 263 at 270

86 Australian Law Reform Commission Equality Before the Law: Justice for Women (ALRC Report 69, Part 1, 1994) at [9.45].

$87 S v S[1999]$ NZFLR 625 (HC) at 632. 
compliance. ${ }^{88}$ Undertakings in this context are voluntary commitments by the petitioner to protect the child or mother upon return to the other country, and courts sometimes use these as a precondition for the return of the child. ${ }^{89}$ They are arguably ineffective as they are both unenforceable in the country of habitual residence and rarely implemented, with one study illustrating that 67 per cent of undertakings were not implemented following the child's return. ${ }^{90}$ No matter the protection promised, abusers may breach protection or restraining orders and the child may remain in danger due to physical proximity with the abusing parent. ${ }^{91}$ Geographic distance may be the only assured avenue to diminish the likelihood of future harm. ${ }^{92}$ There is an issue of the abusers following victims overseas, thus avenues of limiting this risk ought to be considered.

Kaye argues that a court ordering return due to a finding that the habitual residence has adequate protection laws would seem particularly ironic to those women who have fled the country precisely because the courts and community failed to take necessary steps to protect them from abuse or hold the abuser accountable in the first place. ${ }^{93}$

Return to a habitual residence may cause further psychological damage to children. ${ }^{94}$ While a country may be able to protect a child from explicit physical risks, the authorities lack the "potent weaponry against deep-seated psychological harm occasioned by return to the country in which the sexual or physical violence is alleged to have occurred". 95 The "grave risk" defence was established in Coates v Bowden, as whilst Australian authorities could keep the children safe, they could not absolve their anxiety about returning, especially as the father sought contact with the children. ${ }^{96}$ Such anxiety and stress associated with return may only be avoided by a non-return order.

The reality is that no legal system can ever fully protect women and children from violence. ${ }^{97}$ Once the truth of this statement is realised, it becomes clear that New Zealand's current approach to

88 Kaye, above n 2, at 201.

89 Karen Williams "Fleeing Domestic Violence: A Proposal to Change the Inadequacies of the Hague Convention on the Civil Aspects of International Child Abduction in Domestic Violence Cases" (2011) 4 J Marshall LJ 39 at 66.

90 At 67

91 Mockett, above n 3, at 220.

92 Weiner, above n 45, at 626.

93 Kaye, above n 2, at 198.

$94 \mathrm{HCCH}$, above n 34, at 33 .

95 Caldwell, above n 40, at 179.

96 Coates v Bowden HC Auckland CIV-2006-404-7028, 30 May 2007 at [48].

97 Kaye, above n 2, at 199. 
the "grave risk" defence, focused on the mere presence of protection mechanisms, will not adequately protect victims of domestic violence.

\section{Authority and Convention Purposes}

Judge Ellis has stated there is simply nothing in the Convention which suggests the defences should be applied in such a reluctant or restrictive way. ${ }^{98}$ The adoption of this narrow approach is especially surprising in these cases, as the background to the child's abduction is far removed from the type of mischief targeted by Convention drafters. ${ }^{99}$ In situations where the abducting parent is fleeing from domestic violence, the purposes of the Convention become significantly less relevant.

Kaye commented that the "[r]isks of harm and trauma to the child will vary depending on the methods, motive and character of the abductor." 100 The summary return mechanism operates on two key assumptions: first, that summary return is in the best interests of the child; and secondly, that all child abduction is harmful. ${ }^{101}$ By requiring the abducting party to show that the habitual residence lacks the ability to adequately protect the child on return, the court is effectively reinforcing the belief that all child abduction is harmful and speedy return is the best option. In cases of domestic violence, the harm caused by the abduction is likely inconsequential in comparison to the abuse which occurred in the country of habitual residence. Logic suggests that a child secure in the knowledge that they will not be forced to return to the place of abuse will inhabit a different psychological profile after abduction than a child abducted from a primary caregiver and forced to live underground. ${ }^{102}$ A child's individual best interests in domestic violence situations will likely be best met by declining to order return, countering Convention purposes.

The Supreme Court, in Secretary for Justice v HJ, whilst discussing the "settled" defence in s 106(1)(a), reasoned that because deterrence is no longer possible at this stage of the proceedings, the welfare of the child should be a starting point and the most important factor in the exercise of discretion, thus giving greater weight to the individual child. ${ }^{103}$ This statement may be analogised to the "grave risk" defence as, similarly, goals of deterrence are no longer of vital importance. If women stay in an abusive situation, deterred by the potential application of the Convention, then the Convention's underlying goal of protecting children will be undermined. In $A v A$, the mother took the

98 P v B [Hague Convention] [2002] NZFLR 353 at [90].

99 Caldwell, above n 40, at 174.

100 Kaye, above n 2, at 192.

101 Mockett, above n 3, at 202.

102 Weiner, above n 45, at 619 .

103 Secretary for Justice v HJ, above n 27, at [86]. 
child into hiding as she was so concerned for the welfare of the child if the return order was made. ${ }^{104}$ The mother's actions illustrate a lack of faith in the judicial system and its ability to protect vulnerable members of society. The Convention does not seem to deter parties in these situations.

Domestic violence cases should not be forced uneasily into the paradigm abduction framework which the Convention was drafted to remedy. Purposes of limited relevance to domestic violence cases should not be relied on to uphold the status quo.

\section{Procedural Unfairness}

King commented that, procedurally, applicants for, and parties opposing, return of the child are treated unequally in a number of significant respects. ${ }^{105}$ Although this was in response to United Kingdom proceedings, the similarity in approaches means the same procedural difficulties are likely faced by New Zealand applicants.

The return proceedings are likely fair in the case of the typical abduction paradigm. However, in "grave risk" cases, the current approach by New Zealand courts places an unfair onus on the abductor. After proving the grave risk produced by the domestic violence, abductors must then "confront the even more challenging task of proving the practical inadequacy of the laws of the other country, all in a context where courts readily trust the sufficiency of another governments laws as they appear on paper". ${ }^{106}$ This is a near impossible burden to discharge, thus placing the abductor at a distinct procedural disadvantage to the party petitioning for return.

The policy of expediency does not readily accommodate expert reports, oral evidence or counsel for the child. ${ }^{107}$ This can make the establishment of s 106(1)(c) even more difficult. Evidence is increasingly important in these cases as the pattern of violence is crucial to understanding the potential future risk posed by the abuser. ${ }^{108}$ Such evidence may be given adequate consideration in the discretionary stage of the inquiry, but cases rarely proceed to this. Evidence helping to establish an abductor's case is overlooked in favour of prompt return.

Due to geographical closeness, a majority of cases of international child abduction occur between Australia and New Zealand. As New Zealand courts have the highest respect for the courts of Australia and would be very unlikely to critique the latter's child protection laws, the "grave risk" defence is

104 Mockett, above n 3, at 209.

105 Shani M King "The Hague Convention and Domestic Violence: Proposals for Balancing the Policies of Discouraging Child Abduction and Protecting Children from Domestic Violence" (2013) 47 Fam LQ 299 at 306.

106 Quillen, above n 46, at 631.

107 Mockett, above n 3, at 212.

108 Weiner, above n 45, at 695. 
rendered essentially redundant in situations involving these countries. ${ }^{109}$ New Zealand courts are often too willing to trust the courts of the requesting state to protect the child and, consequently, there is little the abductor can do to contest return.

\section{E Welfare and Best Interests of the Child Inquiry}

Generally, there were high levels of support in Parliament for the introduction of the Convention. However concern was raised that the courts' discretion may not be wide enough to prevent a court from returning a child to a detrimental situation, especially given the fundamental principle in New Zealand law that the welfare of the child is paramount. ${ }^{110}$

Section 4 of COCA outlines that a child's welfare and best interests ought to be a paramount consideration, but s 4(4) stresses this paramountcy does not limit the Convention provisions, seemingly mitigating the importance of a child's welfare and best interests in these inquiries. It seems strange to rely on another country to prioritise a child's welfare and best interests whilst we allow it to be overtly excluded from our own Convention inquiries. By considering children an indistinguishable group and dictating that summary return is in their best interest, there is little scope for consideration of the individual child.

Caldwell has suggested that the future viability and public acceptance of the Convention could be placed at risk if a more child-centred approach is not adopted. ${ }^{111}$ This is relevant due to the increased international and domestic awareness of the importance of children's rights. It cannot be allowable to treat a child as a legal object, so that they become invisible inside the mechanisms of the Convention. ${ }^{112}$

There is a key tension between the summary return mechanism, which favours the perceived general interests of the child, and the fundamental principle in New Zealand family law and art 3 of UNCROC that the welfare of the child should be paramount. ${ }^{113}$ Courts are beginning to recognise the importance of considering the welfare and best interests inquiry, however, if this is not considered until the latter discretionary exercise, then the child's interests are not the paramount consideration. Due regard may not even be given to the child's welfare and best interests as the current approach by New Zealand Courts in establishing the "grave risk" defence in the first place effectively blocks the latter discretionary stage.

109 Boshier, above n 49, at 68.

110 (15 May 1990) 570 NZPD 1541.

111 Caldwell, above n 40, at 165 .

112 Ponjavic and Vlaskovic, above n 21, at 49.

113 Mockett, above n 3, at 200. 


\section{SUGGESTED CHANGES IN APPROACH}

This section offers suggested changes to the current approach by reconsidering the structure of the inquiry, attempting to mitigate some of the aforementioned issues.

\section{A Establishment of the "Grave Risk" Defence and the Exercise of Discretion}

The Convention provides a legislative framework for, and streamlining of, the return process, which can facilitate expedient return. However, these benefits are most notably witnessed in those paradigm cases the Convention was drafted to resolve. Domestic violence victims do not fit into this typical abduction paradigm, making the current approach unsatisfactory.

Tapp posed the question of whether a Convention premised on conditions and legal concepts which existed in 1980 can remain viable in the 21 st century. ${ }^{114}$ An entire reworking of the Convention text would be problematic on a range of levels, requiring compromise by the international community. A better approach might be a reconsideration of the way we currently interpret and implement the Convention. Changes should occur within the current framework via changing practices, thus avoiding having to develop a new Convention when the existing one generally works well in paradigm cases. Mockett commented that the best way to conform to UNCROC and fundamental family law principles is for courts to move towards a more flexible approach which would allow for situations in which an order for return can be refused where it is clearly not in the best interests of the child. ${ }^{115}$

If the court accepts that evidence of domestic violence meets the "grave risk" threshold, then $\mathrm{s}$ 106(1)(c) should be established. The consideration into the adequacy of another country's child protection laws and mechanisms should not be another hurdle for the abductor to prove in establishing the defence. Rather, it is a factor which should be considered in the exercise of discretion alongside Convention principles, and the child's welfare and best interests. Courts should avoid presuming contracting states have adequate protection laws and instead, consider evidence as to whether protection can be assured in reality. If the adequacy inquiry occurs in the exercise of discretion, Courts have the scope to consider a range of evidence such as the history of the abuser and abuse, prior breaches of protection orders, and the tangible risk of harm to the child which return may generate.

In recent decades, New Zealand courts have made comments which appear to hint at a shift in approach, or at the very least, dissatisfaction with the current approach. The Court of Appeal in $H J v$ Secretary for Justice remarked that it had no difficulty with the proposition that the grave risk exception could be invoked to refuse a child's return to a country possessing a perfectly adequate legal system. ${ }^{116}$ Whilst the current approach blocks this possibility, this statement seems to leave the gate

\footnotetext{
114 Tapp, above n 20 , at 80 .

115 Mockett, above n 3, at 214.

$116 H J v$ Secretary for Justice, above n 48, at [31].
} 
open for a wider interpretation of the defence. In El Sayad $v$ Secretary for Justice the Judge stated that the limitation of the "grave risk" exception that harm must arise out of return to a country appears to misread the Convention when a wider interpretation is more appropriate. ${ }^{117}$ Glazebrook $\mathrm{J}$ in Punter $v$ Secretary for Justice noted that evolution in construction is entirely permissible under art 31(3)(b) of the Vienna Convention on the Law of Treaties 1969, which allows for changes in interpretation to adequately reflect current state practice. ${ }^{118}$ If states fully consented to the Convention in first instance via signing and ratification, they ought to consent to subsequent developments to ensure the Convention continues to achieve its primary goal; the protection of children. Mockett also referred to the Vienna Convention as providing the opportunity to adapt the current application of the Convention to meet the changing context of child abduction. ${ }^{119}$ However, she stressed that a "balance must be struck between allowing the Convention to respond to changes in society and ensuring the essential elements of the Convention remain functional". ${ }^{120}$ Due to societal changes, reflective of the changing abduction paradigm and increasing emphasis on the importance of the protection of domestic violence victims and rights of the child, variation in the approach to the "grave risk" defence should be justifiable. This is particularly so as the change in gender dynamics underpinning abductions has impacted upon the effectiveness of the Convention's exceptions to return. ${ }^{121}$ The shift in interpretation of overseas contracting states, as discussed, seems to indicate practice is changing. Indeed the New Zealand Law Society remarks there seems to be a softening of judicial interpretation of the Convention principles in cases where domestic violence is raised. ${ }^{122}$

A shift in practice in the way the courts currently implement the defence is needed and the opportunity for a reinterpretation is provided by the Vienna Convention, alongside evidence of dissatisfaction by domestic and international courts in some cases with the current approach. The key barrier for domestic violence victims currently is establishing the habitual residence has inadequate protection laws. Once the necessity to show this is removed from the establishment of the "grave risk" defence, and shifted into the discretionary inquiry (thus still given due consideration), the protection of victims will be better safeguarded.

117 El Sayad v Secretary for Justice [2003] 1 NZLR 349 (HC) at [57].

118 Punter v Secretary for Justice [2004] 2 NZLR 28 at [11]-[12]; and Vienna Convention on the Law of Treaties 1155 UNTS 331 (opened for signature 23 May 1969, entered into force 27 January 1980), art 31.

119 Mockett, above n 3, at 233.

120 At 233.

121 Bozin, above n 64, at 30.

122 Margaret Casey and Lex de Jong International Issues for Family Lawyers (New Zealand Law Society, 19 May 2003) at 4. 


\section{B Appointment of a Lawyer for the Child}

The compulsory appointment of a lawyer for the child in Convention proceedings may act as another means by which the child's welfare, best interests and protection can be promoted.

Pitman comments that it is disconcerting the Convention neither requires nor suggests the appointment of a lawyer for the child. ${ }^{123}$ This is especially troubling in cases evoking the "grave risk" exemption where a child's welfare and best interests are at risk. Concern has been expressed at the practical implications of giving children separate representation and the delays and costs this may entail, and it is thus thought best to be confined to exceptional cases. ${ }^{124}$ However, as has been illustrated, Convention purposes such as speed and deterrence are of limited applicability in cases involving domestic violence. Under COCA, a lawyer may be appointed to represent a child in proceedings under s 7 . However, this is not compulsory; instead it is limited to situations where the judge has concerns for a child's safety or well-being and considers such an appointment necessary. Family Court guidelines have recommended the appointment of a lawyer for the child in any case where a s 106 defence is raised unless the Court is satisfied that the appointment would serve no useful purpose. Judges must also consider the interplay with expert reports, Central Authority functions and importance of speedy proceedings. ${ }^{125}$ There is the possibility for lawyers to be involved, but this is not routinely implemented in practice.

It would be encouraging to see the compulsory appointment of a lawyer for the child in Convention proceedings where domestic violence allegations are raised. Alongside the reconceptualisation of factors to be considered in establishing the "grave risk" defence, this is another potentially valuable mechanism to ensure the paramountcy of a child's welfare and best interests.

\section{BENEFITS AND CRITIQUES OF THE SUGGESTED CHANGES IN APPROACH}

The proposed shift of the position of the adequacy inquiry into the exercise of discretion and compulsory appointment of lawyer for the child in all cases involving domestic violence allegations will help to mitigate the aforementioned issues with the current approach. It is also useful to briefly consider possible critiques this shift may attract and how these may be justified or mitigated.

123 Elizabeth Pitman "Making the Interests of the Child Paramount: Representation for Children in the Hague Convention on the Civil Aspects of International Child Abduction" (2009) 17 Cardozo J Intl \& Comp L 515 at 517 .

124 Jane Fortin Children's Rights and the Developing Law (3rd ed, Cambridge University Press, Cambridge, 2009) at 261.

125 Family Court "Family Court Caseflow Management Practice Note" at (24 March 2011) <www.justice.govt.nz> at 85 . 


\section{A Protection of Victims}

The suggested approach offers better protection for victims. Close physical proximity created by the return order puts children at risk of both physical and psychological abuse. Moreover, if the abuser has a history of breaching protection orders, it is impossible for the habitual residence to guarantee the safety of victims. Even if harm is not to the child directly, the effects of emotional abuse on children witnessing family violence are well documented. ${ }^{126}$ Rather than a limited inquiry, the meaningful test should be to inquire whether the children are safe in fact. ${ }^{127}$

Whilst the grave risk defence is difficult to establish, it has been argued this is justified as the taking parent, if concerned for the child's well-being, ought to and should have raised concerns in the child's country of habitual residence. However some parents may have already made numerous complaints, and others may fear repercussions if disclosure is made. These parents abduct the child because they honestly believe the habitual residence is unable to offer protection.

At its heart, the Convention aims to protect children. Since the Convention was enacted, the strength of the concern for the best interests of the child has formidably increased, thus increasing the space for national authorities to interpret the exemptions more flexibly and widely in line with this. ${ }^{128}$ A wider approach allows for greater consistency with international and domestic child-centred law, promoting the paramountcy of a child's welfare and best interests. The adequacy consideration will occur alongside the welfare and best interests inquiry rather than acting as a prerequisite. A child should not be returned where it is clear that return will cause harm, does not provide any benefit to the child, and is clearly not in their welfare and best interests. ${ }^{129}$

UNCROC is one of the most universally accepted human rights documents in history, ratified by 197 countries (including New Zealand in 1993), hence placing children at the focus of the spread of human rights generally. ${ }^{130}$ UNCROC is guided by principles of provision, participation and protection, with the best interests of the child a paramount consideration under art 3(1). This paramountcy principle is echoed in s 4 of COCA, and when considering a welfare and best interests inquiry within this legislation, s 5 principles should be considered. The majority of the Supreme Court in Kacem v Bashir stressed that there should be no weighing of these principles, with the exception of s 5(a). Parliament used the language that courts must protect a child from all forms of violence from

126 Dudge de Jong and Ingrid Squire Domestic Violence - radical changes (New Zealand Law Society, 9 June 2010) at 1 .

127 Caldwell, above n 40, at 178.

128 Ponjavic and Vlaskovic, above n 21, at 46.

129 Schuz, above n 35 , at 451.

130 Boshier, above n 49, at 63. 
all persons including members of a child's family. ${ }^{131}$ This suggests the protection of children is of the utmost importance in the welfare and best interests inquiry. The shift of inquiry ensures that this consideration is given due weight, better upholding domestic and international law, and in cases where it is clearly not in the child's welfare and best interests for a return order to be granted, their protection will be ensured.

\section{B Evidential Issues}

The suggested approach can help to mitigate evidential issues. Under the current approach, it is rare that the abducting party will be able to prove that the habitual residence lacks adequate protection laws, thus rarely allowing for the invocation of the wider discretionary stage. The issue of grave risk is fact-intensive and appropriate evidence will need to be presented as to the nature of alleged harm and ability of the state to alleviate this. ${ }^{132}$ Once rebutting the presumption that Convention parties have adequate protection laws is no longer necessary to establish the defence, abductors may focus on proving the violence alleged and the subsequent real risk of future harm. The suggested shift in approach helps to ensure that the Convention is not another obstacle for women seeking to escape abusive situations. ${ }^{133}$

A potential critique is that the relaxing of the evidentiary burden on the abducting party may result in taking parents raising domestic violence allegations as a way to circumvent international relocation procedures, generally intended to take place in the state of the child's habitual residence. ${ }^{134}$ Article 19 of the Convention reflects this concern, stating that decisions concerning return shall not be taken to be a determination on the merits of any custody issue. Individuals who voluntarily choose to live in a country should be held to have accepted that country's legal system for any contingencies that may arise. ${ }^{135}$

Boshier argues that, whilst the summary nature of the Convention dominates, it does not prevent a welfare inquiry; rather, it determines in a timely fashion the contracting state in which such an inquiry should take place. ${ }^{136}$ Domestic violence cases are of a different nature to paradigm Convention cases and once abuse is substantiated, a welfare inquiry is necessary to determine the result which will best protect victims. If care is taken in ensuring allegations are verified, and the

131 Kacem v Bashir [2010] NZSC 112, [2011] 2 NZLR 1 at [22].

132 Caldwell, above n 40, at 186.

133 Weiner, above n 45, at 600 .

$134 \mathrm{HCCH}$, above n 34, at 34.

135 Weiner, above n 45, at 646.

136 Boshier, above n 37, at 251. 
suggested change in approach allowing for a wider welfare inquiry is limited to these cases, this issue should be alleviated.

\section{Convention Purposes}

\section{Comity}

Whilst the suggested changes in approach allow for wider considerations, it has been stressed that any expansion of the "grave risk" defence must carefully be balanced with the Convention's fundamental aim of international comity. ${ }^{137}$

Potential implications for comity may arise due to a finding that a habitual residence does not have adequate child protection laws. Any such finding of official ineptitude or incompetence would carry with it the potential to create considerable offence and would accordingly need to be undertaken with the utmost delicacy and sensitivity. ${ }^{138}$ Arguably, the suggested approach is more sympathetic to comity. Rather than requiring courts to find a country cannot adequately protect a child in order to establish s 106(1)(c), this factor is given due consideration alongside other factors. Courts need not critique the habitual residence outright. Whilst the change in approach mitigates the role of the contracting state in proceedings, ensuring the protection of domestic violence victims should be paramount.

The focus should be on the abuser and their history of violence, because as mentioned, no state can guarantee safety. Protection in fact should be crucial. As judges in both the requesting and requested state will inevitably share the same instinct to protect the child, a more child-centred understanding of the defence can be expected to occasion little judicial affront. ${ }^{139}$

\section{Deterrence}

In order for the Convention to work, signatory countries must hold fast to the primary objective of immediate return of children wrongfully removed, as anything less would obliterate the underlying intent and purposes of the Convention, notably deterrence. ${ }^{140}$

There are several issues with deterrence and other Convention goals being used to justify retaining the status quo. Tapp comments that the Convention is not an effective deterrent as few people act

137 Melissa S Wills "Interpreting the Hague Convention on International Child Abduction: Why American Courts Need to Reconcile the Rights of Non-Custodial Parents, the Best Interests of Abducted Children, and the Underlying Objectives of the Hague Convention" (2006) 25 Rev Lit 423 at 427.

138 Caldwell, above n 40, at 177.

139 At 190.

140 Jan McMillan "Getting Them Back: The Disappointing Reality of Return Orders Under the Hague Convention on the Civil Aspects of International Child Abduction" (1997) 14 JAAML 99 at 130. 
entirely rationally under stress. ${ }^{141}$ Where a violent relationship breaks down, people are more likely to base their actions on their emotional needs and protection of their children, rather than on strict conformity with the law. Deterrence assumes that discouraging international child abduction is a categorically desirable goal, however the change in the atypical abduction scenario suggests this is no longer the case. ${ }^{142}$ The shift in approach may lengthen proceedings, mitigating administrative efficiency, yet this is arguably justifiable as it will be limited to cases involving allegations of domestic violence. The goal of child safety, interwoven into the fabric of the "grave risk" defence, must patently trump the more general Convention goals of deterrence and speedy return, with courts refraining from getting preoccupied by the need to make an example of the parent's behaviour. ${ }^{143}$

\section{Merits Inquiry}

Overlapping with comity, the Convention outlines that the judicial authorities of the contracting state shall not decide on the merits of a case until it has been determined a return order should not be made. ${ }^{144}$ An inquiry into harm should not be used as a vehicle to litigate a child's best interests, rather these should be dealt with in the eventual custody hearing which ought to occur in the country of habitual residence. If the Convention country engages in the merits inquiry, the central issue is it risks imposing its own subjective value judgements upon the country of habitual residence. ${ }^{145}$

In some situations an inquiry into a child's welfare and best interests is inextricably linked with the need to engage in a merits inquiry. Whilst a merits inquiry is undesirable, it is arguable that in certain exceptional cases, where there is evidence of violence, perhaps the risk of imposing subjective views and threatening comity is justified to protect children. There are certainly some cases where a child's unilateral removal is justified and in fact in their best interests. ${ }^{146}$

\section{Consistency with Other Jurisdictions}

Chambers $\mathbf{J}$ stressed in White $v$ Northumberland that Hague Convention disputes ought to be determined on a uniform international basis. ${ }^{147}$ The potential implications of allowing inconsistent

141 Tapp, above n 20, at 77.

142 Davies, above n 19, at 240.

143 Caldwell, above n 40, at 188 .

144 Hague Convention, above n 1, art 16.

145 Bozin, above n 64, at 28.

146 At 41

147 White v Northumberland [2006] NZFLR 1105 (CA) at [53]. 
application has been suggested to result in an undermining of the Convention's core objectives. ${ }^{148}$ However, consistency can be a problematic goal, requiring extensive knowledge of overseas practices.

Despite the importance of international consistency, states have implemented and interpreted the Convention in diverse ways. Caldwell indicated that the "most cursory study of overseas jurisdictions reveals quite wide national variations in state and judicial practices", most clearly illustrated in the "striking divergences in return rates". ${ }^{149}$ The issue of the treatment of domestic violence victims was raised at the last Special Commission, suggesting a growing awareness that a global shift in approach is required. As the suggested change in approach still features an inquiry into the adequacy of the habitual residence's child protection laws, albeit at a later stage in the proceedings, it is arguably still consistent with overseas approaches, though it is relaxing the conventional narrow approach to establishing the defence. The earlier section on overseas approaches suggests a change in interpretation is already underway in other Convention states.

\section{CONCLUSION}

Domestic violence cases are of a different nature to the typical paradigm abduction cases which the Convention was drafted to remedy. The current judicial approach to s 106(1)(c) in cases of domestic violence is unduly narrow, and effectively blocks the exercise of discretion where the child's welfare and best interests may be considered. An inquiry which shifts the consideration of the adequacy of a habitual residence's protection laws into the exercise of discretion allows all factors to be given due consideration, ensuring that the protection of children is paramount.

This article has briefly contextualised the Convention and considered its implementation in New Zealand. It explains how New Zealand and overseas courts have approached the "grave risk" defence in cases of domestic violence, critiquing such an approach for blocking the welfare and best interests inquiry and failing to adequately protect victims. Drawing authority from case law and the Vienna Convention, a shift in the current implementation of the Convention was suggested, and the benefits and critiques of this were briefly examined. Whilst there is a risk that the purposes of the Convention may be undermined, such a shift in approach would be limited to domestic violence cases, and such mischief was not originally contemplated by drafters of the Convention anyway.

As Lubin stresses, "it is imperative that the Hague Convention remain current to address today's trends rather than yesterday's presumptions". ${ }^{150}$ Contrary to entrenched belief, not all international child abduction is inherently harmful. Child victims of domestic violence should not be made to suffer for the sake of general deterrence.

148 Nelson, above n 75, at 310 .

149 Caldwell, above n 40, at 167.

150 Barbara Lubin "International Parental Child Abduction: Conceptualising New Remedies through Application of the Hague Convention" (2005) 4 Wash U Global Stud L Rev 415 at 418. 